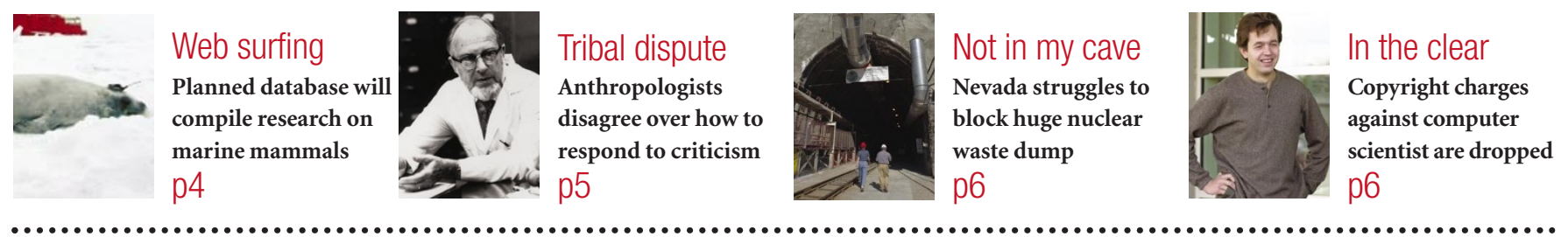

\title{
German task force outraged by changes to science fraud report
}

\section{Quirin Schiermeier, Munich}

Investigations into Germany's largest case of scientific misconduct have ended in shrill discord. Members of an independent task force set up to investigate the scandal by the DFG, Germany's main research granting body, are now complaining that the agency has watered down their report.

Accusations of scientific fraud were first raised in 1997 against two cancer researchers, Friedhelm Herrmann and Marion Brach, who worked together at the Max Delbrück Centre for Molecular Medicine in Berlin in the early 1990s. As investigations continued, allegations of data fabrication extended to more and more papers. Together with subsequent scandals, the case has sparked fears that misconduct may be rife in German clinical research.

In its final report into the Herrmann and Brach affair, published in June 2000, the sixmember task force concluded that data in at least 94 papers had either definitely or "highly probably" been manipulated (see Nature 405, 871-872; 2000). But since then, a bitter row has been simmering between the task force's members and the DFG.

Under pressure from the lawyers of one researcher under suspicion, Lothar Kanz, now at the University of Tübingen, the DFG deleted passages from the task force's report describing alleged irregularities in two papers, published in Blood (84, 1421-1426; 1994) and The New England Journal of Medicine (333, 283-287; 1995). The papers were co-authored by Kanz, his Tübingen colleague Wolfram Brugger and Roland Mertelsmann of the University of Freiburg.

The dispute has boiled over in recent weeks. Ulf Rapp, a cell biologist from the University of Würzburg and head of the task force, complained about the "unauthorized manipulation" of the task force's report in a 19 November letter, signed by four other task-force members, to DFG president Ernst-Ludwig Winnacker. In his response, Winnacker defended the deletions, arguing that the press conference that accompanied the report's publication would otherwise have had to be cancelled. "This would have been regarded in public as a victory for the

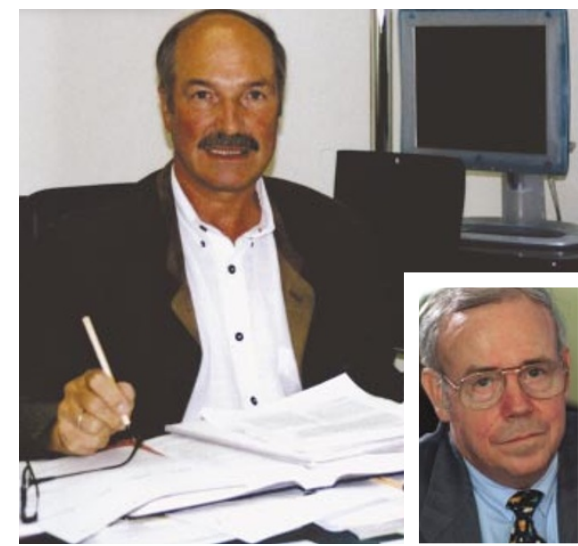

Taken to task: Rapp has complained to Winnacker (inset) about changes to the task force's findings.

scientists accused of scientific misconduct," he claimed.

Rapp replied in a letter on 17 December: "By playing down striking manipulations of data, the DFG has departed altogether from its role as keeper of good scientific practice." He now says that "the matter is likely to be finished up in court", and argues that the DFG did not have the authority to alter the task force's report.

The DFG eventually banned Kanz and
Brugger from serving as peer reviewers for two years, and has issued new guidelines on good scientific practice and clinical research. Mertelsmann, a prominent gene therapist, received a five-year ban.

Rapp feels disillusioned by his experience. "I now understand that the DFG represents the state of affairs in clinical research, and that you cannot expect much more from it than lip service," he told Nature. "There must be more transparent ways of making public what goes wrong. Sweeping things under the carpet because of fear of being sued is not an option."

Rapp wants the DFG to publish an index, in English, of all contaminated publications, either in an international scientific journal or on the Internet. He also argues that the agency is not the right body to deal with allegations of misconduct. "What we need is a truly independent panel to handle investigations," he says.

Eberhard Hildt, who worked as a postdoc with Herrmann and Brach at the University of Ulm and first raised the alarm over the suspect data, agrees. "It is a shame that papers involving fabricated data are still being quoted, and that young researchers might build on them," he says.

\section{Body identified as missing biologist}

Erika Check, Washington

The body of Don Wiley, the prizewinning structural biologist who went missing in November, was found on 21 December. Hydroelectric workers spotted his body snagged on a tree in the Mississippi River, more than 450 kilometres downstream of the bridge near Memphis where his hire car was abandoned (see Nature 414, 475; 2001).

Wiley, a professor at Harvard University, had won a Lasker award and the Japan Prize for his work on the structure of major histocompatibility complex proteins, which are involved in immune responses. "This is devastating for his family and only slightly less so for our department," says Harvard colleague Jack Strominger, who shared those awards.

Wiley had last been seen on 15 November at a dinner for St Jude Children's Research Hospital in Memphis, where he served as a member of its scientific advisory board. Those who were present are stunned by Wiley's death. He was "in great spirits, talking about science, art, politics and his family", says William Evans, deputy director of the hospital. "To us who were with him and who knew him, we felt it was inconceivable that he could do any harm to himself."

As Nature went to press, no autopsy information had been released. 